\title{
From Frayed Rope to Tight Strings: Negotiating Non-Profit Governance in a Neoliberal State
}

\author{
Casey Ready, Ph.D. \\ Trent University, Frost Centre for Canadian Studies and Indigenous Studies
}

Neoliberal policies have created economic disparities and increased the gap between the rich and the poor in Canada. The Mulroney government initiated neoliberal revisions to the Canadian social welfare state as it quietly changed complex regulations that impacted the welfare and wellbeing of Canadians. This government worked "by stealth" and with little consultation to dismantle key components of the social welfare state, while publicly pronouncing its sacred value. In Ontario, neoliberal policies are identified with the Harris government's visible and public attack on the poor, on women and on those marginalized by race. The Harris government made significant cuts to services offered by non-governmental organizations (NGOs) and, in particular, to women's organizations and advocacy groups. This paper examines the impact of neoliberalism by exploring changes through such policies in the relationship between the state and non-profit organizations in Ontario. It is based on initial findings from qualitative research conducted in 2010 and 2011 with three YWCA organizations. It characterizes a shift from the way NGO-state relationships were depicted by Katherine Scott in 2003 as a "frayed rope" about to break, to being represented by an image of multiple "tight strings." This research forms part of a dissertation examining how the neoliberal policies that have reduced government support for, and downloaded responsibilities to, the non-profit sector have affected the capacity of community-based women's organizations to implement a feminist agenda in their work with women. The timeframe studied, from 2003 to 2008, builds on the now extensive scholarly research on the impact of neoliberal policies that occurred from 1995 to 2003, the years led by Progressive Conservative Premiers Mike Harris and Ernie Eves. It closely examines continuities and discontinuities between the two governments, revealing many dangers for women buried in complex and often misunderstood relationships between non-profit organizations and the state.

Key words: Feminism; neoliberalism; social welfare state; non-profit sector; violence against women; gendered poverty

Des politiques néolibérales ont donné lieu à des disparités économiques et augmenté l'écart entre les riches et les pauvres du Canada. Le gouvernement Mulroney a entrepris des modifications néolibérales de l'État social providence, et changé des règlements complexes se répercutant sur le bien-être et la qualité de vie des Canadiens. Ce gouvernement a agi furtivement et sans mener de vastes consultations sur le démantèlement des composantes essentielles de l'État social providence, tout en déclarant publiquement sa valeur sacrée. En Ontario, des politiques néolibérales caractérisent l'attaque ouverte et publique menée par le gouvernement Harris contre les démunis, les femmes et les personnes marginalisées par la race. Le gouvernement Harris a fait des coupures significatives dans les services offerts par les organismes non gouvernementaux $(O N G)$, particulièrement les groupes de défense des droits de la femme et les regroupements de femmes. Cette étude porte sur les répercussions du néolibéralisme en se penchant sur les changements apportés par de telles politiques à la relation entre l'État et les organismes à but non lucratif de l'Ontario. Elle est fondée sur les conclusions primaires d'une recherche qualitative menée en 2010 et 2011 auprès de trois organismes de la $Y W C A$ faisant une distinction dans la relation entre les ONG et l'État qui, décrite par Katherine Scott en 2003 comme une "corde usée» sur le point de se rompre, s'était détériorée en de 
multiples "cordons serrés ».Cette étude s'inscrit dans une dissertation portant sur les politiques néolibérales ayant réduit la participation du gouvernement au secteur des organismes à but non lucratif, ainsi que sa délégation constante de ses responsabilités sur ce dernier, et ayant diminué la capacité des organisations communautaires de femmes à mettre en auvre un agenda féminisme dans le cadre de leurs activités auprès des femmes. La période à l'étude, en l'occurrence 2003 à 2008, s'appuie sur de vastes recherches académiques portant sur l'impact des politiques néolibérales mises en xuvre de 1995 à 2003, années au cours desquelles les Premiers ministres progressistes conservateurs Mike Harris et Ernie Eves étaient au pouvoir. Y sont analysées en détails les différences et la continuité entre les deux gouvernements en et relève de nombreux dangers pour les femmes, dissimulés dans des rapports complexes et souvent mal compris entre les organismes à but non lucratif et l'État.

Mots-clés : féminisme; néolibéralisme; État providence social; secteur à but non lucratif; violence faite aux femmes; différence dans la pauvreté des hommes et des femmes

\section{Introduction}

Neoliberalism is a complex project. It values individual freedom and privileges the primacy of the market over collective claims to welfare, as it proffers the belief that the primary role of the state is to protect and nourish market growth and entrepreneurialism (Harvey, 2005). Neoliberal policies have created economic disparities and increased the gap between the rich and the poor in Canada. Susan Braedley and Meg Luxton (2010) argue that neoliberalism “...is not advancing social justice or equality, but is, instead, reinscribing, intensifying, and creating injustices and inequality" (p. 6). In particular, they show that it is creating and extending the poverty of women and of people marginalized by race. By valuing individual responsibility, neoliberalism fosters blame-the-victim thinking. It has led to women having lower wages and more unpaid work than men, as it has promoted the interests of elite men in maintaining gendered divisions of labour and male privilege (Braedley and Luxton, 2010, p. 15).

This paper examines how three YWCA organizations in Ontario experienced the McGuinty government's new-neoliberal violence against women policies from 2003 to 2008 as continuing, and differing from, the neoliberal policies presented by the Harris-Eves governments from 1995 to 2003. It focuses on the relationship between the YWCAs as non-profit organizations, or NGOs, and the government with the goal of uncovering ways these relationships, and changes in them, affect women served by and working in the YWCAs. It reveals many dangers for women buried in complex and often misunderstood relationships between non-profit organizations and the state, including continuing dangers for women served by, and working in, the YWCAs during the years studied of the McGuinty government.

This paper examines changes in the relationship between the state and non-profit organizations (NGOs) based on initial findings from research conducted in 2010 and 2011 with three YWCA organizations in Ontario. This research forms part of a dissertation examining how neoliberal policies, which reduced government support for and downloaded responsibilities to the non-profit sector, have affected the capacity of the YWCAs to implement a feminist agenda in their work with women. The timeframe studied, from 2003 to 2008, builds on the now extensive scholarly research (Bashevkin, 2002; Chunn \& Gavigan, 2004; Little, 2003; Miller, 1998; OAITH, 1996, 1998; Scott, 2003) on the impact of neoliberal policies that occurred from 1995 to 2003, the years led by Progressive Conservative Premiers Mike Harris and Ernie Eves.

Findings in this paper are drawn from interviews and focus groups in 2010 and 2011 with forty-one people, including clients, staff and volunteers of the YWCAs and representatives of government and of activist groups. Findings also include data from a literature review and a review of documents from three YWCAs, the Ontario government and activist groups. They reveal ways the YWCAs experienced pressures in their connections with neoliberal governments and, in particular, changes in these relationships in the shift from the Harris government, known for its extreme funding cuts and direct attacks on women, to the McGuinty government. While the McGuinty government brought some relief to 
the YWCAs and lessened the ideological war on women initiated by the Harris government, this research suggests that it did not immediately offer significant new funds to the violence-against-women sector. Funding increases during the McGuinty government's first term were minimal. It was only in its second term, following significant advocacy by the violence-against-women sector, that the McGuinty government allocated meaningful funding increases to the YWCAs. Findings further reveal that this new funding came with a clear neoliberal twist. I characterize changes in this relationship as a shift from Katherine Scott's 2003 depiction of the NGO-state relationship as a "frayed rope" to it being represented instead by an image of multiple "tight strings". Scott's frayed rope suggests a single and strong relationship between the state and the non-profit sector. This strength as a thick rope was eroded by funding cuts and regulation changes through neoliberal governments, to the point that it was badly frayed and about to break.

The image of multiple tight strings portrays funds re-invested from the state to the non-profit sector by new-neoliberal governments through a number of new, specific and closely monitored service contracts. The number of strings represents the multiplicity of relationships between NGOs and the state created by these contracts. Their tightness underscores how funds were invested in the non-profit sector with the new expectations and heightened accountability requirements of the McGuinty administration. This image corresponds with research claiming that new-neoliberal or social investment governments, such as the McGuinty Liberals, offer new funds for services but with high levels of state regulation and accountability as these funds are "reinserted in new ways" (Chunn and Gavigan, 2004, p.227). The tautness of the strings portrays tensions created by a pull-back from NGOs receiving and also resisting conditions on these newly invested funds. In the case of the YWCAs, this resistance was strengthened by their feminist goals and agendas as they negotiated funding agreements to meet the needs of the women they serve.

The Canadian social welfare state expanded significantly in post-World War II following key assumptions held by British economist John Maynard Keynes that the state had a role to play in addressing the failures of the market. The Keynesian social welfare state was marked by growth in areas such as health, education, social welfare and income security programs (Cossman and Fudge, 2002, p. 10). Governments with neoliberal agendas began to dismantle key components of the Keynesian social welfare in the mid-1970s. The Mulroney government began a large scale, but initially quiet, project of dismantling the social welfare state following the 1985 report of the Macdonald Commission and the subsequent 1988 Free Trade Agreement. This included selling state assets, cutting funding for social programs and attacking advocacy groups representing women, people of colour, and First Nations (Cossman and Fudge, 2002, p. 14). Cuts to the social welfare state were accelerated by the Chrétien government as it eliminated the Canada Assistance Plan (CAP) and the Established Program Financing Act (EPFA) and reduced spending on health and social services by 7 billion dollars from 1995 to 1997 (Cossman and Fudge, 2002, p. 16). In Ontario, neoliberal policies dismantling the social welfare state are identified with the Harris government's visible and public attack on the poor, on women and on those marginalized by race. The Harris government made significant cuts to services offered by NGOs and, in particular, to women's organizations and advocacy groups.

The policies of the McGuinty government are said to share some assumptions of the more classic neoliberalism of the previous Harris government, but to also bring new features more consistent with "centre-left" governments. Scholars have defined such governments as "social investment," "Third Way," "new-neoliberal," "post-neoliberal," "contingent neoliberal" and "roll-out neoliberal" states (Dobrowolsky, 2002, 2009; Hackworth, 2008). The term "new-neoliberal" is used in this paper as it reflects the continuation of key tenets of neoliberalism while also suggesting that some aspects of neoliberalism are new or changed.

\section{Methods and Theory}

Research for this study includes a literature review; examination of publicly available documents from the Ontario government, the YWCAs and violence-against-women activist groups. Interviews and focus 
groups with 41 volunteers, staff and clients of three YWCAs, representatives of the Ontario government, and activists were conducted. Findings are reported in direct or block quotations, reflecting the actual words of participants. Trends, conclusions and comparisons drawn from this research reflect my own views and may not be shared by the people interviewed.

The interviews and focus groups followed a written set of questions approved by Trent University's Research Ethics Board. Interviews were conducted in a semi-structured format. Questions were designed to seek comments on the broader themes and issues guiding this work related to the impact of neoliberalism on the feminist agenda of the YWCAs. They varied slightly in length for the interviews (Appendix 1), focus groups (Appendix 2) and external interviews held with the government representatives and activists (Appendix 3). Interviews were recorded, with participant consent. Notes from focus groups were kept on flip charts. I analysed all transcribed notes by coding them as containing content in relation to the research questions. In total, comments were coded and sorted into nine areas of content: (1) the Harris government, (2) the McGuinty government, (3) feminism, (4) NGO/state relationships, (5) funding, (6) fundraising, (7) advocacy, (8) work and, (9) professionalization.

Two central questions explored were: (1) how the three YWCAs experienced the McGuinty government's first term violence-against-women policies as continuing and differing from, the neoliberal assumptions presented by the Harris government and, (2) how these YWCAs defined and negotiated a feminist agenda in their violence-against-women work in response to this government. The term, a feminist agenda, referred to ways that feminist beliefs influenced and were incorporated in the work of the YWCAs. Participants in the study were asked questions (as shown in Appendices 1,2 and 3) about the feminist agenda of the YWCAs and the subsequent impact of the Harris and McGuinty government. Findings reported in this paper were frequently cited by participants in response to questions about ways that their services were most affected by neoliberalism, areas where they felt their YWCA work would, and would not, be defined as feminist, and strategies their YWCAs put in place to respond to government changes.

This research is situated in political economy theories that place the social welfare state in a legitimating role within a broader capital state (Offe, 1984). It draws on understandings of the social welfare state that view governments to have complex and often contradictory functions, following theories that "a great deal of state policy...[is] directed at moderating the glare of the inequalities of capitalism" and at legitimizing state actions (Panitch, 1977, p. 228). It builds on a view of the history of social welfare in Ontario which uncovered a "galling paradox" of increasing welfare dependency in the midst of plenty (Struthers, 1994, p. 258). Further, it extends an understanding that that the social welfare state supports concepts of a "social minimum" and "less eligibility" (Chunn \& Gavigan, 2004; Little, 2003; Struthers, 1994) in that supports received from the state must always be lower than what is needed, or never be enough, in order to keep people working for minimal wages. The social welfare state operating within a capitalist state faces inconsistencies and paradoxes as it is designed to support the accumulation of capital and to also maintain the legitimacy of the state (Offe, 1984; Panitch, 1977). This understanding makes visible obscure connections and interdependencies between the social welfare state and capitalism. It supports contentions that the social welfare state in a modern capital society has a "permanent legitimation problem" and exists in a constant state of crisis through its contradictory roles (Offe, 1984, p. 23). Contradictions in state roles can be seen in tensions between a stated goal of supporting women and children in contrast to unstated goals of regulating women's morality and behaviour, as shown in the treatment of single mothers through Mothers' Allowance programs (Little, 2003).

I share a concern that there has been a retreat from class analysis in the academy connected with the shift to postmodern theories and that this retreat is "one of neoliberalism's most effective ideological weapons" (Naples, 2003, p. 69, quoting Rosemary Hennessy). Deeper connections are needed between academic and activist work, including renewed emphasis on class-based analysis in research, to aid efforts to expose and resist neoliberal policies that increase poverty, inequality, and the marginalization of women. With this concern, this research draws on feminist standpoint theory that places importance on the material and the concrete, as well as on praxis (Naples, 2003), and builds bridges between modern and 
postmodern theories. The approach for this study draws on theories that value differing and changing perspectives from the situated knowledges and multiple standpoints of women (Harstock, 1996; HesseBiber\& Leavey, 2007). It is informed by feminist research theory contending that both discursive research methodologies and those based on more concrete, material matters are valid and that the combination of these can overcome challenges in activist research (Naples, 2003). The struggle to combine views from practical, material studies of the social welfare state with postmodern theories that examine governmentality and the relations of ruling enriches this research (Rose, O'Malley, \& Valverde, 2006; Smith, 2005).

\section{Results}

This study of the three YWCAs reveals a changing relationship between them and the state. It characterizes this relationship as representing a shift from the NGO-state relationship depicted by Scott (2003) as a frayed rope, to an image of this relationship found in the current research to now be better reflected as one of multiple tight strings.

The argument for this research is that the alliance between feminism and neoliberalism in the work of the YWCAs during the time studied was complex and at times uneasy due to contradictions between feminism and neoliberalism. It was also anticipated that the funding and policy approaches for the YWCA violence-against-women programs by the new-neoliberal McGuinty government would mirror, in many ways, those of the Harris government. Initial findings confirm and diverge from this argument.

The negative impact of the policies and funding of the Harris government on the violenceagainst-women programs of the YWCAs was confirmed by study participants and in documents reviewed. However, the findings differ from those anticipated where they demonstrate that the McGuinty government's approach did not mirror that of the Harris government. There were significant and subtle funding and policy changes affecting the shelter work of the YWCAs under McGuinty. An immediate shift took place in the first term of the McGuinty government as they displayed more women-friendly attitudes, including increasing consultations with women in the violence-against-women sector. Yet there were only minor, if welcome, funding improvements during McGuinty's first term, such as renewed cost of living increases. In the first year of their second term, following a strong lobby by violence-againstwomen advocates through the Step it Up Campaign, the McGuinty government returned funds cut by the Harris government in 1995. Also, it released its Domestic Violence Action Plan, offering increased funds for a new Transitional Housing Support Program. It took concerted advocacy and negotiation by women's groups, including but not exclusively the YWCAs, to bring about the significant funding enhancements in McGuinty's second term. Even with communications and funding improvements, policies of the McGuinty government still reflected neoliberal values and the struggles experienced in the violence against women sector were not over.

\section{Shift from Keynesian to Neoliberal Social Welfare State}

The Keynesian social welfare state has been systematically reduced in Canada since the mid-1970s through the implementation of neoliberal policies. Marjorie Cohen (1997) documents the deconstruction of social welfare through federal funding cuts from 1985 to 1995, including significant cuts to advocacy, women's and citizen's groups. Changes made by the Harris government were consistent with neoliberal policies of privatization, familialization, decentralization, commodification and criminalization (Bezanson, 2006). Changes implemented by this government to welfare policies began immediately following their 1995 election with cuts of 5.5 billion dollars in funding from almost all ministries, agencies and not-for-profit agencies (Bezanson, 2006). The Harris government attacked Ontario's social assistance programs materially and ideologically (Little, 2003). These attacks came in the form of: (1) benefit rates were cut by $21.6 \%$, (2) spouse-in-the-house regulations abolished in 1987 were reintroduced, (3) a separate provincial program of Family Benefit Assistance (FBA) targeted principally at single 
mothers was eliminated, and (4) a new system of eligibility based on compulsory workfare and job training for all employable recipients was implemented (Little, 2003).

Although it was assumed that neoliberal policies would soften with the shift to new Third Way governments, such as that of McGuinty, these new regimes did not move away from neoliberalism. Sylvia Bashevkin (2002) describes this as a "puzzle" in the policies of Third Way politicians in Canada, the United States and Britain (p. 4). Bashevkin examines the policies of governments led by Tony Blair, Bill Clinton and Jean Chrétien, who were defined as post-conservative leaders but found to pursue "fundamentally similar or even more regressive policy directions" than their neoliberal predecessors (Bashevkin, 2002, p. 4). Bashevkin argues that Third Way politicians such as Chretien adopted rhetoric about family values, single mothers and poverty, but with significantly different meanings than feminist discourse about care-giving and nurturing. She describes this strategy as employing the "same terms for very different purposes" (Bashevkin, 2002, p. 141).

\section{"Harris Lingered On”}

A growing body of research examines changes in the shift from the neoliberal policies of the Harris government to those of the McGuinty government. While the McGuinty government reframed rhetoric about neoliberalism and reinstated some funding, it continued to operate under neoliberal assumptions. Studies on social housing found that while centre-left governments such as the McGuinty government seldom espouse or "foreground neoliberal principles" (Hackworth, 2008, p. 4), they remain effective in maintaining neoliberalism in their policies and practices. By using rhetoric more friendly or favourable to social housing, while still implementing neoliberal policies that limited the development of social housing, new-neoliberal governments were found to also effectively mute activism (Hackworth, 2008).

The negative impacts of the Harris government's neoliberal policies continued during both terms of the McGuinty government. One of the activists interviewed cited this as a reflection that "Harris lingered on." This lingering on allowed the McGuinty government to appear softer in its policies and funding, while anti-feminist policies and discourses affecting violence-against-women services created by the Harris government continued to have a negative impact on women. As many of the people interviewed were not familiar with the term neoliberalism, it is interpreted in this study that the statement that Harris lingered on also meant that neoliberalism lingered on under the McGuinty government.

\section{From Frayed Rope to Tight Strings}

Parallel with services provided directly by governments through the social welfare state in Canada and significantly part of the social welfare state, are services offered by NGOs. This sector emerged in Canada in the late $19^{\text {th }}$ century with a relationship to the state characterized as "uneasy" and "fraught with tension" (Brock, 2001, p. 264). The non-profit sector and NGOs grew significantly in Canada with funding provided during the expansion of the post-war Keynesian social welfare state such as the development of children's aid societies in the late $19^{\text {th }}$ century - the first private organizations to deliver statutory government programs (Miller, 1998). They flourished in the 1960s and 1970s with the Pearson government establishing groups to foster citizen participation and increasing government grants, and through Trudeau's promotion of a just society (Miller, 1998). Overall, Canadian registered charities tripled from 1960 to 1990 (Miller, 1998). Cuts since then in core funding and a shift to contracts and grants by neoliberal governments led this sector to suffer a crisis of identity as it became more statedriven, hindering its ability to act independently on behalf of citizens (Miller, 1998).

The impact of neoliberalism on the work of a non-profit organization is examined by Susan Arai and Donald Reid in a study assessing the effects of funding cuts through the Harris government's Bill 26 (the Omnibus Bill) on the social planning council in Ottawa (Arai \& Reid, 2003). Arai and Reid conclude that cuts to the social planning council's funding led not only to a loss of community service but also to a significant loss of volunteer advocacy roles and opportunities for social citizenship. Due to reduced funding, the social planning council was pressured to be involved with direct services, such as food 
banks, breakfast programs and other band aid-type programs, and was thereby less involved with its mandated work of social research, evaluation and advocacy on systemic issues of poverty. Fewer volunteers were recruited and trained to undertake higher level community service roles as more were recruited for technical and menial volunteer roles. These changes limited the possibilities for the social planning council to engage in social development and advocacy work as volunteer roles shifted to support the direct service tasks.

Restructuring of the social welfare state that began in the 1970s has moved the non-profit sector increasingly to the role of a shadow state or a para-state apparatus (Milligan \& Conradson, 2006; Wolch, 1990):

The shadow state carries out welfare state functions, providing essential human services, financial and in-kind benefits, and surveillance of clients. In these activities, it is enabled, regulated and subsidized by the state. But shadow activities are not formally part of the state. They do not involve the same kinds of direct accountability and oversight procedures characteristic of internal state apparatus. Instead, they are subject to state-imposed direct and indirect constraints on their autonomy (Wolch, 1990, p. 41).

Scott (2003) depicted the relationship of NGOs to the state as a deeply frayed rope, about to break. The non-profit sector faced pressures created by the shift from core funding to short-term, project and contract-based funding, from the strain of increased reporting and accountability requirements, and from heightened expectations that they would engage in partnerships. NGOs were left hanging to the state by a frayed rope through increased funding volatility, loss of infrastructure, reporting overloads, an advocacy chill, a human resource chill and an overall situation likened to being a "house of cards" (Scott, 2003, p. xiv-xv).

The Harris government initiated funding changes that had an immediate impact on the YWCAs, their shelter work and their clients. Described as "cuts to the bone" in shelter services, they implemented a five percent overall cut to first stage emergency shelters for abused women, the elimination of counselling and advocacy programs in women's second stage housing and cuts to community counselling and crisis telephone services for abused women (OAITH, 1998). These occurred at the same time as women were deeply affected by the Harris government's cuts to the social welfare state, cuts that were gendered in that they affected women more than men. These included the $21.6 \%$ cut in social assistance noted above as well as cuts to legal aid and family law, narrowed eligibility for social assistance, cuts to child care spaces, cuts to training and education for women, and the elimination of funding to key advocacy groups such as OAITH and tenants rights groups (OAITH, 1998). The current study contains responses by women involved with the three YWCAs to the policies and funding of the Harris government, with findings showing almost unanimous agreement that this constituted a war on women and on the shelter services of the YWCAs. In a YWCA staff focus group, participants emphasized that it was clearly a very difficult time, one they referred to as "desperate", though not without room available for advocacy and agency by the YWCAs.

These findings follow arguments that changes to the social welfare state through neoliberal policies are "explicitly gendered" even as they claim a "gender-neutral" position (Bezanson, 2006, p. 36). Neoliberalism is gendered as it de-funds women's organizations, marginalizes women's activist groups, and appropriates feminist discourse for its own ends. Neoliberal changes shift responsibilities from the state to the market and the family, pressuring women into "taking up the slack for cuts in social services and for labour market insecurity" (Bezanson, 2006, p. 36).

The shift to the McGuinty government was viewed by an Executive Director of a YWCA as an "enormous relief," bringing great hope to the people working at the YWCAs. The YWCAs experienced an immediate change in attitude and communications from the new government. Participants said that they felt valued for their work; they were consulted and felt that the government atmosphere was much more woman-friendly. Some new money flowed to the YWCAs during this time, but the increases were minimal and did not restore the funding lost through cuts by the Harris government. According to an 
interviewed advocate, it was only in the second term of the McGuinty government, following concerted province-wide advocacy, that significant funds were reinstated to the YWCAs and the shelters.

Diversities were found in the relationships between the YWCAs and the Ontario government. Each YWCA had a personal and individual relationship with their Ontario government funders based on their own approach and connections. Yet similarities also existed in the relationships between the YWCAs and the government. They all experienced heightened expectations to produce reports on government defined service outcomes. They also experienced tensions as they worked to serve women who were experiencing ongoing pressures of poverty. They reported pressures from changing expectations in the relationship between the government and their Executive Directors; increased reporting and accountability requirements; demands on working conditions for women; requirements for salary freezes; and heightened expectations for fundraising.

The YWCAs experienced a sudden openness in their relationships with the Ontario government with the shift to the McGuinty government. One Executive Director stated, "suddenly we seemed to have a government that actually did care. They sent people out to do the research and to do the thinking, who obviously did get it." Another Executive Director commented on this as well, noting:

Well, certainly the rhetoric changed. Certainly, the government, the M.P.P.s and bureaucrats were more open, they would meet with the social service sector, which had not happened for a very long time. So the whole approach changed, it was a way friendlier environment...you know for the first time in four or five years, the government was welcoming and that was an enormous relief. Even if they weren't able to do things right away that they were willing to hear what you had to say was a blessed relief.

\section{Pressures from the "New Public Managerialism"}

Theories of governmentality and the relations of ruling reveal ways of assessing how the state can appear to limit its size and withdraw its involvement from services while in reality it is still "governing from a distance" through regulations that are dispersed and often hard to recognise (Rose, O'Malley \& Valverde, 2006, p. 95). Though the "new public managerialism" powers held by the state appear benign, as they are hidden among diffuse, grey and boring procedures, while in fact they have a powerful hold on the experiences of NGOs (Smith, 2005, p. 217). The increased reporting and tight accountability expectations initiated by the Harris government continued and even increased with the McGuinty government. These marked a shift to corporate governance and accountability mechanisms, such as a reliance on evidence-based research and outcomes-based measurement systems, a shift seen as a "misfit" with the work of community organizations (Bonisteel \& Green, 2005, p. 22). Tensions between neoliberalism and feminism are embedded in differing methods of accountability and evaluation (Bonisteel \& Green, 2005). Neoliberalism favours evaluations based on positivist science and its claims to neutrality, objectivity, and experimental research; alternately, feminist research evaluation values "ways of knowing the world that are rooted in the experience of women" (Bonisteel \& Green, 2005, p. 23). Reflexivity, the social location of the researcher and the participation of research participants are important to feminist research. Power shifted with the new public managerialism, as "knowledge production [was]...untied from the community and re-tied to the powerful institutions that are authorized to generate it, such as governments, universities, hospitals and funders" (Bonisteel \& Green, 2005, p. 25).

These forms of accountability and evaluation construct many of the tight strings in the relationship between the YWCAs and the government. They define how services are provided, creating tensions and even tighter strings. One YWCA staff member referred to these processes as reflective of "robotic thinking":

There's now a huge administration burden on organizations, without the dollars, because we've never, you know, we're slim in terms of resources. We're spending a lot of time now doing, the dot the i's and cross the t's, and trying to make a woman tell us [what we want to hear] so that we can get 
the funding...there's a lot more paperwork...they're trying to get so fine tuned that it's not going to make any sense, I call it robotic thinking.

Accountability mechanisms shaped the services provided by the YWCAs and created tensions in the ways they responded to the needs of women served. This was illustrated in an example described as "creaming," where government requirements for reports on successful services impacted the way one of the YWCA offered services, reducing access to services for the women who needed them the most. The Executive Director of this YWCA cited this in relation to an employment program, but it is relevant to the current study on violence-against-women services as it demonstrates the effects of outcome measures on programming. Her comments were:

So, instead of having a program that will help women with many barriers to getting employment funded on a block basis, an annual block grant, they have moved to an outcomes way of paying. So, our conviction is that that way of funding, when you only pay for outcomes, leads our whole sector, not us, our whole sector, to do what is called "creaming."... so, you really want to work with the people who are the most close to getting a job, so that when they get that job, you're paid. So the women that we work with have multiple barriers to employment - and it might take a year of intensive working with them for them to get a job, as opposed to working with someone for a month who gets a job. And yet, for all the work that we do for a year, we may get paid, but we may not. They may have advanced tremendously but they still don't have that job.

In a second example of the impact of accountability measures on service delivery, one of the YWCA staff participants spoke of "the need to rescue women." The reference to rescuing women was an interpretation by this staff member based on the reports their YWCA submitted to the government. The government wanted them to account for the number of women they freed from violent situations. This requirement placed this organization in a strained relationship with the government as it called on them to work in ways that moved them away from their feminist values. The requirement for this YWCA to demonstrate they had rescued or saved women contradicted their feminist agenda to have women define their own options and plans. A staff member said:

That's always been a bit of a struggle given that statistics, a lot of the government folks or funders that want statistics are looking for, you know, how we impacted women, assuming that there's more of a rescue - that we saved her from this, that we saved her from that, and it really isn't us, it's really the woman. So looking at building her strengths is basically how we work with women - help her find them, locate them and build them, and then be able to move on with her life.

Pay equity put one YWCA in a Catch-22 situation during both the Harris and McGuinty eras. This YWCA supported the goals of pay equity for women to be paid equally to men. Government legislation required the YWCA to have a pay equity plan in place and to make annual increases in salaries to achieve pay equity, but it did not provide the additional funding needed to achieve these goals. As a result, pay equity increases were made by the YWCA but at the expense of agency services and reserves. The Executive Director of this YWCA described this issue:

It was one of those situations that was just unbelievable that we could be caught in this Catch 22 ...And so I started writing letters and letters... I wrote interminable letters. I wrote to the Harris government people and then as soon as McGuinty came in I started writing to him, saying, "it used to be their policy but now its yours, so now what are you doing to do about it because you are now the one that's doing this to us and are you aware that you are going to drive this organization into bankruptcy?"

And 
That was a very, very difficult lobby because I came to understand that no government was going to truly embrace it because they understood that we were so underpaid that it was going to be a crippling cost. But what the McGuinty government did was to start to give increases that at least covered those pay equity obligations, so that therefore there was some relief...It's like you're killing us with this program that we think is truly important - so that was very difficult.

Substantiated by interviews with an Executive Director and a staff member, further change embedded in relations of ruling between the government and the YWCAs was a requirement that the Executive Director of one of the YWCAs advise the Ministry of her schedule from 8:00 a.m. to 5:00 p.m. every day so that she was available to respond at any time to a questions posed by or to the Minister. This requirement reinforced the notion of the NGOs as a shadow state and the image of the strings between the NGO and the state being both shortened and tightened.

\section{Dangers for Women: Increased Use of Gender-Neutral Language}

While violence against women has a long history, it has often been hidden from public view, cloaked in a "veil of words" obscuring the violence and the patriarchal power relations involved (Duffy and Momirov, 1997, p. 10, 13). Jane Jenson (2008) suggested that there is "a need to worry" (p. 38) about the dangers created for women by the policies of new-neoliberal or social investment states. Through their focus on children and on future results, new-neoliberal states pay less attention to the here and now and to the immediate needs of women and their families. As these social investment states "are at work: (1) folding gender in and (2) writing women out" (Jenson, 2008, p. 138), they obscure the visibility of the inequalities faced by women.

Neoliberal and new-neoliberal governments favour anti-feminist and gender-neutral discourses and approaches to violence against women work; they favour terms which render women and the systemic issues that lead to violence against them invisible (Collier, 2008, 2009, 2010). The current study examined the use of feminist and gender-neutral terms in the annual reports of the three YWCAs. Feminist language includes terms such as "violence against women," "women's equality," "feminist," "feminism," and "structural inequality," while gender-neutral language refers to "domestic violence," "family violence," "wife assault or abuse," "law and order issues" and passive descriptions such as "women are beaten" (Collier, 2010, p. 9).

This research revealed differences in the use of this language by each of the YWCAs and found a significant shift when comparing the use of language during the terms of the two governments. Based on this examination of YWCA annual reports, it was found that during the Harris era, feminist terminology was used in two-thirds $(66.7 \%)$ of all references to violence-against-women work by the YWCAs studied. This was almost reversed during the McGuinty years, as the use of gender-neutral language grew to almost two-thirds $(60.9 \%)$ of the total references to violence-against-women work. This finding suggests that the YWCAs shifted their use of language to better match the dominant language used by the government. While this may have benefited them in their funding and relationships with the state, it raises questions about the dangers this creates for women as language which obscures systemic issues is adopted by those working in the violence-against-women sector.

\section{Dangers for Women: Continuing Poverty}

Even with the increased openness of the McGuinty government, a key tension that did not change with them was their failure to address the poverty that women faced. This government opened communications with the shelters and increased some funding but they did not address the levels of poverty brought about by the Harris government. One of the Executive Directors commented that this had a major impact on women served: 
Certainly the McGuinty government tried to do some catch-up as far as ... their funding for VAW shelters. But, I just really think...to go back to the welfare rates, really, the impact upon the women that we work with was the most pronounced.

The observation that poverty continued for women relates to the aforementioned comment by an activist which noted that "Harris lingers on." Effects of the Harris government lingered on for the women served by the YWCAs as they struggled with ongoing issues related to poverty. They continued in the strain on community resources. Even as McGuinty restored some funding to the YWCAs, the poverty of the women served and the limitations affecting other community resources, such as housing, legal aid and child care, continued. This had devastating consequence for the women served. It also placed enormous pressures on the YWCAs and other organizations serving women. An activist claimed this to be the "biggest disappointment" with the McGuinty government:

I think probably, I'll speak only for myself here, but I suspect others would agree, the biggest disappointment [with the McGuinty government] was the lack of attention to women's poverty. So you know, no real welfare reform, I think the cuts under Harris were something like $35 \%$ and I think really we haven't seen anything significant to come back from that.

One of the activists noted that there had not yet been a return to pre-Harris days. This participant stated:

One of the biggest damages of a real right wing reactive government, is that you never get back to where you were which was not good enough to begin with, but you start to think of what you had before as being really great and different from what it is. So it's almost like we all lower our standards and expectations. If the McGuinty government had preceded the Harris government, we wouldn't have thought it was a really great government.

To this person, the effects of Harris lingered on, not only directly, but also in changes made as expectations and the vision of what was needed were lowered.

To one staff member, the failure of the McGuinty government to address poverty and its impact on women created pressures for the YWCA to "become everything" to the women they served:

What we're finding is that what women expect from us, it's just increased tenfold. So you know, we've become, it's just like everything... what's happening, women are waiting longer and longer for housing...most of our women have been here almost a year.... the expectations on us are huge.

While at the YWCAs, women who had experienced violence found refuge not only through shelter from violence for themselves and their children, but also through the availability of food, laundry facilities, transportation and other resources and supports. There was a significant contrast for women between living in poverty and living in a YWCA shelter, a place where a staff member commented they "never run out of milk." This produced huge expectations and pressures on the YWCAs. A staff member explained:

We try to have really good food, we have lots of donations, you know, the house is clean, there's always food in the fridge, we never run out of milk, and yet when women go out there ...sometimes, their only choice for a better life is to deal with, to be involved with another man who is abusive. So, what are we really doing to in terms of breaking that cycle, right? And if women could get out there and have a decent wage, and have housing that's affordable, it's just creating, it's creating [a] huge vortex of what our expectations are, we get women calling us all the time, you know, we have a little food bank downstairs, women still need food, so it's, the expectations on us are huge. 
A staff member noted that their YWCA felt the pressure from "becoming... like everything" to their clients. This participant stated that due to the combined effects of ongoing poverty among the women served by the YWCAs, the modest increases in the YWCA's funding, and reduced services due to the continued funding challenges faced by other community organizations, their YWCA faced tenfold increases in expectations from the women they served.

\section{Conclusions}

According to an interviewed activist, the McGuinty government's failure to address poverty for women demonstrates how neoliberalism lingered on under its administration. It lingered on for the women served by the YWCAs as they struggled with ongoing issues related to poverty, violence, and with the lack of support for housing, child care and legal services. It lingered further for the YWCAs as they faced ongoing funding restraints. The YWCAs were in the difficult position of serving women whose needs were greater at the same time as their access to resources were reduced.

The YWCAs felt pressure to act as lifeboats and to become everything to the women they served due to reduced and altered funding, short-term contracts, new accountability expectations, gender-neutral language, the need to rescue and save women, and increasing poverty among the women served by their violence-against-women programs. These expectations increased the importance of connections with the state; they also brought greater dangers for women. Clients at the YWCA shelters stayed longer than before, as access to second stage and transitional housing were also reduced. Staff at the YWCAs worked harder "to do more, multi-task more" so that "service delivery did not get worse" in the face of reduced funding (staff focus group). The YWCAs became lifeboats to their clients, a role that created risks to the YWCAs and the women who worked there while also being a valuable form of resistance.

About the Author: Casey Ready, Ph.D. (TRENT UNIVERSITY), M.S.W. (UNIVERSITY OF TORONTO), B.S.W. (UNIVERSITY OF WESTERN ONTARIO). Casey successfully defended her doctoral thesis in September 2012. She has experience in social research, policy development, community engagement and service delivery related to social and community services offered by government and the non-profit sector, including as Executive Director of three NGOs. Her research interests include gender issues in the social welfare state, the relationship of the non-profit sector to the social welfare state, violence against women, women and poverty, community engagement and social justice. Email: catherineready@trentu.ca or casey.ready@utoronto.ca.

\section{References}

Arai, S.M., Reid, D. G. (2003). Impacts of a neo-liberal policy shift on citizenship and the voluntary sector: A policy delphi with social planning organizations. Canadian Review of Social Policy, 52, 67-92.

Bashevkin, S. (2002). Welfare hot buttons: Women, work and social policy reform. Toronto: University of Toronto Press.

Bezanson, K. (2006). Gender, the State and Social Reproduction: Household Insecurity in Neo-Liberal Times. Toronto: University of Toronto Press.

Bonisteel, M., Green, L. (2005). Implications for the shrinking space for feminist anti-violence advocacy. Fredricton, New Brunswick: Presented at the 2005 Canadian Social Welfare Policy Conference.

Braedley, S., Luxton, M., (Eds). (2010). Neoliberalism and Everyday Life. Montreal and Kingston, London, Ithaca: McGill-Queen's University Press.

Brock, K. (2001). Democracy is coming: The new interest in NGOs, civil society, and the third sector, The Philanthropist, 16 (4), 263-271. 
Canadian Centre for Philanthropy. (2003). The Capacity to Serve: A Qualitative Study of the Challenges CanadCCFacing Canada's Nonprofit and Voluntary Organizations. Toronto: Canadian Centre for Philanthropy.

Chunn, D. E., Gavigan, S. (2004). Welfare law, welfare fraud and the moral regulation of the never deserving poor. Social and Legal Studies, 13 (2), 219-243.

Cohen, M. G. (1997). From the welfare state to vampire capitalism. In P. Evens, G. Wekerle, (Eds). Women and the Canadian welfare state (pp. 28 -70). Toronto: University of Toronto Press.

Collier, C. N. (2008). Neoliberalism and violence against women: Can retrenchment convergence explain the path of a provincial anti-violence policy, 1985-2005? Canadian Journal of Political Science, 41(1), 19-42.

Collier, C. N. (2009). Violence against women or violence against "people"? Assessing the impact of neoliberalism and "post-neoliberalism" and anti-violence policy in Ontario and British Columbia. In A. Dobrowolsky, (Ed). Women and public policy in Canada. Neoliberalism and after? (pp. 199186). Toronto: Oxford University Press.

Collier, C. N. (June 2010). The disappearing woman? Locating gender equality in contemporary child care and anti-violence policy debates in Canada. Unpublished manuscript.

Cossman, B. (2002). Family Feuds: Neo-Liberal and Neo-Conservative Visions of the Reprivatization Project. In J. Fudge, B. Cossman (Eds). Privatization, Law and the Challenge to Feminism (pp. 169217). Toronto: University of Toronto Press.

Cossman, B., Fudge, J., (2002). Privatization, Law and the Challenge to Feminism. Toronto: University of Toronto Press.

Dobrowolsky, A., (2009). Introduction: Neoliberalism and after? In A. Dobrowolsky (Ed). Women and Public Policy in Canada. Neoliberalism and After? (pp. 1-24). Toronto: Oxford University Press.

Dobrowolsky, A. (Autumn 2002). Rhetoric versus reality: The figure of the child and new labour's strategic 'social investment state'. Studies in Political Economy, 69, 43-73.

Duffy, A., Momirov, J., Family Violence: A Canadian Introduction. James Lorimer \& Company, 1997.

Eakin, L. (2004). Community capacity draining: The impacts of current funding practices on non-profit community organizations. Toronto: Community Social Planning Council of Toronto.

Eakin, L. (2007). We can't afford to do business this way: A study of the administrative burder resulting from funder accountability and compliance practices. Toronto: Wellesley Institute.

Hackworth, J. (Spring 2008). The durability of roll-out neoliberalism under centre-left governance: The case of Ontario's social housing sector. Studies in Political Economy, 81, 7-26.

Harstock, N. (1996). Postmodernism and political change: Issues for feminist theory. In S. Hekman (Ed). Feminist interpretations of Foucault (pp. 39-58). University Park, P. A.: Pennsylvania University Press.

Harvey, D. (2005). A Brief History of Neoliberalism. New York: Oxford University Press.

Hesse-Biber, S.N., Leavey, P.L., (Eds). (2007). Feminist research practice: A primer. Thousand Oaks, London and New Delhi: Sage Publications.

Little, M. (2003). The leaner, meaner welfare machine: The Ontario conservative government's ideological and material attack on single mothers. In D. Brock (Ed.), Making normal (pp. 235-258). Toronto: Nelson Canada.

Miller, C. (1998). Canadian non-profits in crisis: The need for reform. Social Policy and Administration, 32(4), 401-419.

Milligan, C., Conradson, D. (2006). Landscapes of voluntarism: New spaces for health, welfare and governance. Bristol, U.K.: The Policy Press, University of Bristol.

Naples, N. A. (2003). Feminism and method: Ethnography, discourse analysis and activist research. New York: Routledge.

Offe, C. (1984). J. Keane (Ed). Contradictions of the welfare state. London: Hutchinson.

Ontario Association of Interval and Transition Houses (OAITH). (November 1996). Locked in left out: Impacts of the progressive conservative budget cuts and policy initiatives on abused women and their children in Ontario. Toronto. 
Ontario Association of Interval and Transition Houses (OAITH). (November 1998). Falling through the gender gap: How Ontario government policy continues to fail abused women and their children. Toronto: Ontario Women's Justice Network.

Panitch, L. (1977). The Canadian state: Political economy and political power. Toronto: University of Toronto Press.

Rose, N., O'Malley, P., Valverde, M. (2006). Governmentality. Annual Review Law Society, 2, 83-104.

Scott, K. (2003). Funding Matters: The Impact of Canada's New Funding Regime on Nonprofit and Voluntary Organizations. Canadian Council on Social Development.

Smith, D. E. (2005). Institutional ethnography: A sociology for people. Oxford: AltaMira Press.

Struthers, J. (1994). The limits of affluence: Welfare in Ontario, 1920-1970. Toronto: University of Toronto Press.

Wolch, J. (1990). The shadow state: Government and voluntary sector in transition. New York: The Foundation Centre.

\section{Appendix 1}

Questions for Interviews

\section{An Uneasy Alliance:}

Negotiating Feminism in "New-Neoliberal" Times

1. How long have you been involved with the YWCA?

2. Can you describe what the YWCA does in relation to violence against women (VAW)?

3. In what ways have you been involved with the VAW work of the YWCA?

4. How does your YWCA define its work with women?

5. In this study, feminism is defined broadly as representing "a movement to end sexist oppression" (bell hooks).

a. Does your YWCA identify its work as having a feminist agenda, and if so, what does this mean?

b. Are there ways that the YWCA does its work that you would not define as feminist?

6. I am interested in understanding how policies of the Ontario government have affected the Violence Against Women (VAW) work of the YWCA.

a. What policies and funding approaches did your VAW services experience in the Harris era (1995-2002)

b. Did these approaches change when the McGuinty government came to power in 2003? If yes, how?

c. How has your YWCA responded to the policies of the Harris government?

d. How did they respond to the first term of the McGuinty government?

e. Which aspects of your VAW services have been most affected by the policies of the Harris and McGuinty governments, and how have they been affected?

7. What strategies and initiatives has your YWCA employed in response to government changes?

8. In what ways has your YWCA maintained your VAW services? Have they increased, decreased or changed under these governments?

9. Has your philosophy related to VAW service changed in response to the changes of these governments?

10. Have spaces been found for rethinking and revising the YWCA's VAW services in response to changes in government funding?

a. If yes, what are these changes?

b. In what ways do you feel they are consistent with feminist frameworks?

September 17, 2010 


\section{Appendix 2 \\ Questions for Focus Groups \\ Research Study on How Different Governments Affect Violence Against Women Services}

1. Can you describe what your YWCA does in relation to violence against women?

2. In this study, feminism is defined broadly as representing "a movement to end sexist oppression" (bell hooks).

a. Does your YWCA identify its work as having a feminist agenda, and if so, what does this mean?

b. Are there ways that the YWCA does its work that you would not define as feminist?

3. I am interested in understanding how policies of different Ontario governments have affected the VAW work of the YWCA.

a. What policies and funding approaches did your VAW services experience in the Harris era (1995-2002)?

b. Did these approaches change when the McGuinty government came to power in 2003? If yes, how?

4. What strategies and initiatives has your YWCA employed in response to government changes?

5. In what ways has your YWCA maintained its VAW services?

6. Have spaces been found for rethinking and revising the YWCA's VAW services in response to changes in government funding?

a. If yes, what are these changes?

b. In what ways do you feel they are consistent with feminist frameworks?

September 17, 2010 


\section{Appendix 3}

Questions for Interviews - External Contacts

\section{An Uneasy Alliance:}

Negotiating Feminism in "New-Neoliberal" Times

Student Investigator: Catherine (Casey) Ready, Ph.D. Candidate

Student Faculty Supervisor: Dr. James Struthers

1. How long have you been involved with the VAW work?

2. Can you describe what the YWCA does in relation to violence against women (VAW)?

3. In what ways have you been involved with the VAW work of the YWCA?

4. In this study, feminism is defined broadly as representing "a movement to end sexist oppression" (bell hooks).

a. Would you identify the YWCA as having a feminist agenda, and if so, what does this mean?

b. Are there ways that the YWCA does its work that you would not define as feminist?

5. I am interested in understanding how policies of the Ontario government have affected the Violence Against Women (VAW) work of the YWCA.

a. What policies and funding approaches did VAW services experience in the Harris era (1995-2002)

b. Did these approaches change when the McGuinty government came to power in 2003? If yes, how?

c. In your view, how has the YWCA responded to the policies of the Harris government?

d. How did they respond to the first term of the McGuinty government?

e. Which aspects of the YWCA VAW services have been most affected by the policies of the Harris and McGuinty governments, and how have they been affected?

6. What strategies and initiatives has the YWCA employed in response to government changes?

7. In what ways has the YWCA maintained its VAW services? Have they increased, decreased or changed under these governments?

8. Has the YWCA philosophy related to VAW service changed in response to the changes of these governments?

9. Have spaces been found for rethinking and revising the YWCA's VAW services in response to changes in government funding?

a. If yes, what are these changes?

b. In what ways do you feel they are consistent with feminist frameworks?

September 17, 2010

Revised November 30, 2010 for External Interviews 